\title{
¿Por qué la responsabilidad social universitaria en el proceso formativo de los estudiantes?
}

\section{Why the university social responsibility in the formative process of the students?}

\author{
“La educación es el arma más poderosa \\ que puedes usar para cambiar al mundo". \\ Nelson Mandela, 1918-2013
}

La responsabilidad social, tiene un fuerte impacto en la construcción de los valores de una organización, y las personas que la integra; le sirve como difusión de sus valores, para posicionarse en el medio y también obtener un redito económico. Pero no es de esto lo que se quiere expresar ahora... es el valor de la responsabilidad en el ámbito universitario... en la educación superior, como una estrategia en la formación integral de los profesionales, no solo completando o formando la ciencia propia de la disciplina que el estudiante transita, sino agregándole un plus, del contacto con la realidad concreta y palpable, aprendiendo a trabajar conjuntamente universidad y estamentos públicos o privados donde el alumno, futuro profesional comenzará a realizar sus prácticas, con conciencia de servicio, a los que lo necesitan.

La Responsabilidad Social Universitaria, RSU responde a un modelo de gestión ética, integral y trasversal, que fusiona e impacta en las tres funciones universitarias, que hacen a la educación superior: la formación académica propia de cada carrera, la investigación desde donde se desarrolla los conocimientos y desde la proyección en un lugar determinado, en una realidad social concreta.

Un impacto transversal, hace referencia a una responsabilidad sistémica, interdisciplinaria, es un asunto de todos, no personal, donde interactúan docentes, alumnos y personas de una comunidad concreta. También en un impacto territorial, porque su finalidad es el desarrollo sostenible, social y ambiental, orientadas a transformar la realidad local, regional y nacional, en común acuerdo con su entorno.

La RSU, es la interacción de la universidad con su entorno, contribuyendo al progreso de la sociedad, no es solo una actividad de extensión, lo supera en el sentido que implica una conexión con la

Revista Methodo: Investigación Aplicada a las Ciencias Biológicas. Facultad de Medicina. Universidad Católica de Córdoba. Jacinto Ríos 571 Bo Gral. Paz. X5004FXS. Córdoba. Argentina. Tel.: (54) 3514517299 / Correo: methodo@ucc.edu.ar / Web: methodo.ucc.edu.ar | EDITORIAL Rev. Methodo 2021;6(4):152-154. 
investigación aplicada y la docencia, estableciendo redes de trabajo colaborativo, alianzas entre la universidad y los sectores privados, comunitarios, y públicos municipales, provinciales y /o nacionales.

Los proyectos tienen tres pilares fundamentales:

- Articulación curricular, contenidos y competencias disciplinares, de las cátedras que participan.

- Acción territorial, es un trabajo colaborativo con la sociedad, las instituciones donde se anclan los proyectos, en un tiempo y espacio concreto.

- Promoción del desarrollo económico, social, cultural, e integral tanto del alumno, que participa, como en las instituciones donde se desarrollan.

También es muy importante reconocer el rol de cada uno de los actores, de los docentes como líderes, que coordinan las tareas y evalúan las habilidades y competencias de los alumnos y valoran el impacto social. El rol activo de los alumnos, se ponen en juego sus conocimientos y sus habilidades. Y las instituciones los socios externos, públicos y privados, comunidades barriales, rurales, agrupaciones, con necesidades concretas, que participan en todo el proceso.

Si pensamos desde los orígenes la Universidad Católica de Córdoba, desde su escudo, que tiene un pelicano que significa Jesucristo, según una leyenda de la Edad Media, en el cual el ave se abre el pecho con su pico, se pone encima de las heridas de sus polluelos y le da de nuevo vida. Nos demuestra el valor del compromiso con el otro, ese otro que es un pichón, un pequeño, un desvalido.

El Digesto de nuestra universidad dice:

"La Universidad es... el lugar en el que confluyen los saberes, el espacio de diálogo desde la fe, con la cultura y con la reflexión acerca de la vida de los pueblos y de las personas... Y esa enseñanza provenía de la pedagogía de la realidad...La misión de la Universidad Jesuita no se mide entonces sólo por la cantidad de doctores (algo importantísimo), ni sólo por la cantidad de investigadores o de papers publicados (algo que también es clave), sino por su capacidad de generar personas capaces de transformar la sociedad en un lugar más humano, en el que el rostro humano de Dios resplandezca.... Buscamos, por cierto, transformar conciencias desde una mirada más humana y más cristiana; pero también la Universidad debe tener en su horizonte último la intención de transformar la sociedad desde sus estructuras para que haya de verdad más y mejor educación, acceso a la salud para los pobres, acceso a la justicia para todos y en particular para los sectores más desfavorecidos de la sociedad. Lic. Rafael Velasco, S.J.

La formación de personas de Ciencia, Conciencia y Compromiso constituye la misión de la Universidad, misión que se inspira en el ideal ignaciano de superar constantemente los niveles de excelencia. Aspiramos a ser una universidad que incida en la construcción de un orden social más justo, mediante la formación de graduados y graduadas competentes y comprometidos con su realidad (docencia); a través de la producción de conocimiento socialmente pertinente (investigación); y mediante la proyección social del mismo (extensión) a fin de incidir en políticas públicas que mejoren la calidad de vida en particular de los sectores más desfavorecidos de nuestra sociedad.”

Revista Methodo: Investigación Aplicada a las Ciencias Biológicas. Facultad de Medicina. Universidad Católica de Córdoba. Jacinto Ríos 571 Bo Gral. Paz. X5004FXS. Córdoba. Argentina. Tel.: (54) 3514517299 / Correo: methodo@ucc.edu.ar / Web: methodo.ucc.edu.ar | EDITORIAL Rev. Methodo 2021;6(4):152-154. 
Para cumplir con la misión de la Universidad es imperativo tener acciones concretas, actividades académicas que tengan impacto social, que el alumno salga de los claustros y trabaje en la realidad concreta, realidad en la cual después él trabajara.

La formación no se logra solo en una acción, por eso es importante que sea un proceso, que en cada año de cada carrera y en las distintas asignaturas los alumnos puedan tener una experiencia palpable de la realidad, actividades concretas, pertinentes y continuas.

"Si queremos un mundo de paz y de justicia hay que poner decididamente la inteligencia al servicio del amor”.

Antonine De Saint Exupery, 1900 - 1944

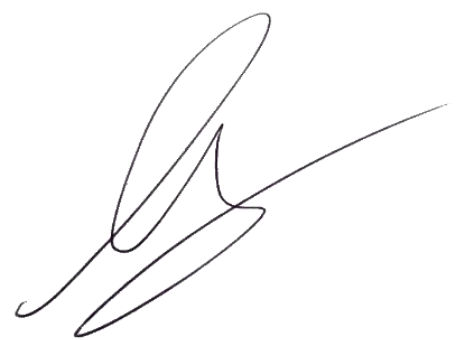

Med. María Eleonora González Docente - Asesora Pastoral

Facultad de Ciencias de la Salud Universidad Católica de Córdoba

Bibliografía

1-Digesto Universidad Católica de Córdoba

2-Ahumada-Tello, E.; Ravina-Ripoll, R. y López-Regalado, M. (2018) Responsabilidad Social Universitaria. Desarrollo de Competitividad organizacional desde el proceso educativo. Rev. Actual.Investig. Educ Vol. 18 n. San José Sep./ Dec. 2018 http://dx.doi.org/10.15517/aie.v18i3.34213

\section{(c) (1) (2)

